\title{
PENERAPAN FUNGSI-FUNGSI MANAJEMEN DALAM MENINGKATKAN MUTU PENDIDIKAN
}

\author{
Syamsuddin \\ Fakultas Tarbiyah dan Keguruan \\ Universitas Islam Negeri Alauddin Makassar
}

\begin{abstract}
:
Improving the quality of education can not be separated from the quality of human resources owned. Therefore, the Education Institution must also be able to meet the human resource needs of both quantity and quality by increasing the educational resources to supply human resource needs in accordance with the demand and improve the local education process by developing the necessary elements and supporting elements. Improving the quality of learning needs to use strategies that can be applied to each institution by taking into account the characteristics of the institution. With qualified human resources, it is hoped that educational institutions will become institutions capable of effectively facing the challenges of the future.
\end{abstract}

Keywords: Management Function, Quality of Education

\section{LATAR BELAKANG MASALAH}

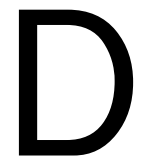

i bidang pendidikan kita telah mengartikan berbagai sukses yang besar dalam sejarah pendidikan di dunia. Apabila banyak Negara maju dewasa ini memerlukan lebih dari 50 tahun untuk mencapai pendidikan universal 6 tahun bagi rakyatnya, Indonesia dapat mencapainya dalam waktu 15 tahun sejak dimulainya rencana pembangunannya pada tahun 1969. Dua puluh tahun kemudian kita mematokkan lagi suatu etape pembangunan selanjutnya dengan lahirnya UU No. 2 tahun 1989 tentang Sistem Pendidikan Nasional. demikianlah beberapa dasar penting yang telah kita letakkan dalam perjalanan pembangunan Pendidikan Nasional. Kalau etape pertama berkenaan dengan berbagai target kuantitatif dalam pembangunan, yang kedua berkaitan dengan cara kepengaturan sistem pembangunan Sistem Pendidikan Nasional. Namun kedua tongkak dasar sector pembangunan pendidikan nasioanal itu baru merupakan dasar bagi pembangunan pada tingkat selanjutnya yang lebih tinggi, yaitu kualitas pendidikan dan penanganan atau manajemen sektor pendidikan itu sebagai bagian dari manajemen pembangunan nasional. Manajemen pendidikan nasional sangat penting karena bukan saja pendidikan itu merupakan kebutuhan dasar manusian Indonesia, bahkan merupakan salah satu dinamisator pembangunan itu sendiri. Dengan demikian, manajemen haruslah merupakan subsistem dari sistem manajemen pembangunan nasional (Tilaar, 1992:3-4).

Melalui sebuah pendidikan kita bisa mendapatkan ilmu pengetahuan karena pendidikan merupakan proses pengubahan sikap dan tingkah laku seseorang atau 
sekelompok orang dalam usaha mendewasakan melalui pelajaran dan pelatihan. Allah SWT. telah memerintahkan kita untuk menuntut ilmu sesuai firman-Nya dalam QS. At-Taubah: 09: 122" Tidak sepatutnya bagi mukminin itu pergi semuanya (ke medan perang). Mengapa tidak pergi dari tiap-tiap golongan di antara mereka beberapa orang untuk memperdalam pengetahuan mereka tentang agama dan untuk memberi peringatan kepada kaumnya apabila mereka Telah kembali kepadanya, supaya mereka itu dapat menjaga dirinya."

Ayat ini menggaris bawahi pentingnya memperdalam ilmu dan menyebarluaskan informasi yang benar terhadap orang lain termasuk peserta didik. Negara Indonesia mumpunyai tujuan pendidikan seperti yang tercantum dalam Undang-Undang Republik Indonesia No. 20 Tahun 2003 Tentang Sistem Pendidikan Nasioanal.

Pendidikan merupakan faktor yang sangat menentukan kualitas bangsa. Sejarah menunjukkan bahwa bangsa yang memperhatikan mutu pendidikan ternyata mengalami perkembangan yang mengagumkan, hal ini seakan membuktikan bahwa hasil pendidikan berupa sumber daya manusia yang bermutu, menjadi dasar yang kokoh bagi perkembangan suatu bangsa. Oleh karenanya mutlak diperlukan langkah-langkah pembaharuan dalam dunia pendidikan yang perlu dilakukan secara mendasar, konsistem dan sistematik (http://clearinghouse.dikmenum.co.id).

"Pendidikan nasional berfungsi mengembangkan kemampuan dan membentuk watak serta peradaban bangsa yang bermartabat dalam rangka mencerdaskan kehidupan bangsa, bertujuan untuk berkembangnya potensi peserta didik agar menjadi manusia yang beriman dan bertakwa kepada tuhan yang Maha Esa, berakhlak mulis, sehat, berilmu, cakap, kreatif, mandiri dan menjadi warga Negara yang demokratis serta bertanggung jawab." (Pasal 3 UU No. 20 Tahun 2003)

Untuk mencapai tujuan Pendidikan Nasional berupaya mengadakan perbaikan dan pembaharuan sistem pendidikan di Indonesia, yaitu dalam bentuk pembaharuan kurikulum, penataan guru, peningkatan manajemen pendidikan, serta pembangunan sarana dan prasarana pendidikan. Dengan pembaharuan ini diharapkan dapat dihasilkan manusia yang kreatif yang sesuai dengan tuntutan zaman, yang pada akhirnya mutu pendidikan di Indonesia meningkat.

Undang-Undang Negara Republik Indonesia Tahun 1945 disingkat UUD 1945. Dalam pembukaan UUD 1945, jelas bahwa pemerintah Negara Indonesia yang dibentuk antara lain dimaksudkan untuk mencerdaskan kehidupan bangsa, maka tentu unsur yang sangat penting dan strategis serta harus dapat mendapatkan perhatian dan perlindungan adalah unsure pendidikan pada semua jenjang pendidikan (pendidikan dasar sampai perguruan tinggi). 
Kualitas manusia Indonesia tersebut dihasilkan melalui penyelenggara pendidikan yang bermutu. Hal ini telah ditetapkan dalam Undang-Undang nomer 20 tahun 2003 tentang sistem pendidikan Nasional, yaitu: "setiap warga Negara mempunyai hak yang sama untuk memperoleh pendidikan yang bermutu" (pasal 5 ayat 1 Undang-Undang Sisdiknas). hal ini merujuk pada pasal 31 ayat (1) UndangUndang dasar Negara Republik Indonesia (Getteng, 2009:13).

Pendidikan nasional pada hakekatnya usaha membudayakan manusia atau memanusiakan manusia. Manusia itu sendiri adalah pribadi yang utuh dan pribadi yang utuh dan pribadi yang kompleks sehingga sulit dipelajari secara tuntas. Oleh karena itu, masalah pendidikan tak akan pernah selesai, sebab hakekat manusia itu sendiri selalu berkembang mengikuti dinamika kehidupannya. Namun tidaklah berarti bahwa pendidikan harus berjalan secara alam. Pendidikan tetap memerlukan inovasi-inovasi sesuai dengan kemajuan ilmu pengetahuan dan teknologi tanpa mengabaikan nilai (Nana, 1996:2).

Peningkatan kualitas pendidikan bukanlah tugas yang rumit tidak hanya berkaitan dengan permasalahan teknis, tetapi mencakup berbagai persoalan yang sangat rumit dan kompleks, baik yang menyangkut perencanaan, pendanaan maupun efesiensi dan efektivitas penyelenggaraan sistem sekolah. Peningkatan kualitas pendidikan juga menuntut manajemen pendidikan yang lebih baik. Sayangnya, selama ini aspek manajemen pendidikan pada berbagai tingkat dan suatu pendidikan belum mendapat perhatian yang serius sehingga seluruh komponen sistem pendidikan kurang berfungsi dengan baik. Lemahnya manajemen pendidikan juga memberikan dampak terhadap efesiensi internal pendidikan yang terlihat dari jumlah peserta didik yang mengulang kelas dan putus sekolah (Mulyasa, 2002).

Manajemen pada umumnya merupakan proses penentuan tujuan atau sasaran yang hendak dicapai dan menetapkan jalan dan sumber yang dipergunakan untuk mencapai tujuan yang seefesien dan seefektif mungkin. Demikian pula halnya jika dikaitkan dengan pendidikan. Respon terhadap harapan tersebut, tentunya tidak lepas dengan adanya usaha pihak sekolah untuk memperbaiki kinerjanya, khususnya dalam menyusun dan melaksanakan manajemen organisasi kependidikan yang tentunya memiliki pengaruh yang besar terhadap kesuksesan pendidikan. Karena dengan bermutunya kualitas penyusunan dan pelaksanaan pendidikan dapat mengantar setiap instansi pada umumnya dalam mencapai kesuksesan (Sagala, 2001:99).

Dalam mewujudkan suatu pendidikan yang bermutu tentunya dibutuhkan suatu manajemen yang baik. Manajemen yang baik itu tentunya mengacu pada fungsi-fungsi manajemen itu sendiri, dimana fungsi-fungsi yang dimaksudkan tidak lain adalah POAC. Manajemen harus di terapkan dalam upaya penyelenggaraan kegiatan belajar mengajar karena dengan menerapkan aspek manajemen seperti perencanaan (planning), pengorganisasian (organizing), pengawasan (controlling), 
serta evaluasi(evaluation), maka kegiatan belajar mengajar dapat berjalan secara terencana, sistematis, berkesinambungan dan mencapai tujuan yang telah diciptakan dalam hal ini peserta didik dapat mencapai standar mutu pendidikan yang telah ditentukan.

Standar mutu proses pembelajaran harus pula ditetapkan, dalam arti bahwa pihak manajemen perlu menerapkan standar mutu proses pembelajaran yang diharapkan dapat berdaya guna untuk mengoptimalkan proses pembelajaran dan untuk melahirkan output yang sesuai, yaitu menguasai standar mutu tersebut.

Berdasarkan latar belakang di atas, maka penulis merumuskan masalah dalam penelitian ini sebagai berikut: "Bagaimana fungsi manajemen dalam meningkatkan mutu pendidikan?"

Penerapan fungsi-fungsi manajemen yang akan diamati dalam penelitian ini adalah: penerapan fungsi-fungsi manajemen dalam meningkatan mutu pendidikan.

\section{PEMBAHASAN}

Penerapan fungsi-fungsi manajemen adalah proses penerapan dari fungsifungsi manajemen yaitu perencanaan, pengorganisasian, pelaksanaan dan pengawasan dalam organisasi untuk mencapai tujuan dengan efektif dan efesien.

Mutu adalah gambaran karakteristik menyeluruh dari barang atau jasa yang menunjukkan kemampuannya dalam memuaskan kebutuhan yang diharapkan atau yang tersirat. Jadi dalam konteks pendidikan, pengertian mutu mencakup input, proses, output pendidikan.

\section{Pengertian Manajemen}

Manajemen secara etimologi berasal dari bahasa inggris management yang dikembangkan dari kata to manage, yang artinya mengatur atau mengelola. Kata manage ini sendiri berasal dari Italia Maneggio yang diadopsi dari bahasa latin managiare, yang berasal dari kata manus yang artinya tangan (Tim Dosen Administrasi Pendidikan UPI, 2011:230). Sedangkan dalam kamus besar bahasa Indonesia kata manajemen mempunyai pengertian sebagai penggunaan sumberdaya secara efektif untuk mencapai sasaran (Yuku, 2013:29). Dalam arti khusus manajemen dipakai bagi pemimpin dan kepemimpinan yaitu orang-orang yang melakukan kegiatan memimpin dalam suatu organisasi.

Manajemen cenderung dikatakan sebagai ilmu maksudnya seseorang yang belajar manajemen tidak pasti akan menjadi seorang menejer yang baik. Adapun pengertian manajemen yang dikemukakan oleh beberapa ahli yaitu:

1. Menurut Andrew F. Sikukula (Dalam Hasibun, 2009:6), mengemukakan bahwa manajemen pada umumnya dikaitkan dengan aktifitas-aktifitas perencanaan, pengorganisasian, pengendalian, penempatan, pengarahan, pemotivasian, komunikasi dan pengambilan kjeputusan yang dilakukan oleh setiap organisasi dengan tujuan untuk mengkoordinasikan sebagai sumberdaya yang dimiliki 
oleh perusahaan sehingga akan di hasilkan suatu produk atau jasa secara efesien.

2. Menurut Terry dan Laslie (Dalam Manullang, 1985:2) mendefenisikan manajemen sebagai suatu proses atau kerangka kerja yang melibatkan bimbingan suatu kelompok orang-orang kearah tujuan organisasional atau maksud nyata, sedangkan Manula mendefenisikan manajemen pada tiga arti yaitu: manajemen sebagai proses, manajemen sebagai kolektifitas orang-orang yang melakukan aktifitas manajemen, manajemen sebagai suatu seni (art) dan sebagai suatu pengetahuan.

3. Menurut Mary Paker Follet (Dalam Fatah, 1996:3) mengatakan bahwa manajemen sebagai seni untuk melaksanakan pekerjaan melalui orang-orang (the art getting things done through people). Defenisi ini perlu mendapatkan perhatian karena berdasarkan kenyataan, manajemen mencapai tujuan organisasi dengan cara mengatur orang lain.

4. Menurut pandangan George R. Terry (Dalam Nawawi, 1998:39) yang mengatakan bahwa manajemen adalah pencapaian tujuan (organisasi) yang sudah ditentukan sebelumnya dengan mempergunakan bantuan orang lain. Pengertian tersebut mengatakan bahwa untuk mencapai tujuan organisasi, terdapat sejumlah manusia yang ikut berperan dan harus diperankan.

Kesimpulan yang dapat saya ambil dari berbagai defenisi-defenisi tersebut bahwa manajemen adalah serangkaian kegiatan yang didalamnya terdapat suatu proses berbeda yaitu planning, organizing, actuating dan controlling sehingga bisa memanfaatkan sumber daya yang ada untuk mencapai tujuan dengan efektif dan efesien.

a. Teori-teori manajemen

1) Teori klasik

Teori klasik berasumsi bahwa pekerja atau manusia itu bersifat rasional, berfikir logis, dan kerja merupakan suatu yang diharapkan. Salah satu teori klasik adalah manajemen ilmiah yang dipelopori Federik W. Taylor. Sasaran pada pendekatan ini adalah kemakmuran maksimum bagi pengusaha dan karyawan. selanjutnya prinsip studi waktu dipelopori oleh Gilbreth menyatakan bahwa semua usaha yang produktif diukur dengan studi waktu secara teliti. Berdasarkan studi waktu muncul prinsip hasil upah yaitu upah diberikan harus sesuai dengan hasil yang besarnya ditentukan dari studi waktu. Pelopor klasik yang lain yaitu Hendri Fayol yang menyatakan ada 5 pedoman manajemen yaitu: perencanaan, pengorganisasian, pengkomandoan, pengkordinasikan dan pengawasan. Prinsipprinsip pokok menurut Fayol:

a). Kesatuan komando,

b). Wewenang harus didelegasikan,

c). Inisiatif harus dimiliki seorang manjer, 
d). Adanya solidaritas kelompok,

e). Prinsip-prinsip tersebut harus bersifat luwes.

Selanjutnya Max weber (Dalam Terry dan Rue, 1992:10) berpendapat bahwa birokrasi merupakan ciri dari pola organisasi yang strukturnya dibuat sedemikian rupa sehingga secara maksimal dapat memanfaatkan tenaga ahli. Karakteristik birokrasi ditandai dengan:

a). Pembagian tugas dan spesialis

b). Hubungan impersonal

c). Adanya hirarki wewenang

d). administrasi secara tertulis

e). pembinaan pengembangan karir

f). tindakan seimbang dengan sumbangan

Setiap individu dalam organisasi mempunyai wewenang yang diatur oleh bebagai peraturan kebijakan dan ketetapan hukum sehingga diperlukan pembagian tugas sesuai dengan spesialis yang dimiliki individu. Birokrasi merupakan usaha untuk menghilangkan tradisi organisasi yang membuat keputusan secara emosional atau ikatan kekeluargaan sehingga mengakibatkan organisasi tidak efektif. Birokrasi juga tidak ada hubungannya dengan prosedur yang berbelit-belit, penundaan pekerjaan, ketidak efesienan dan pemborosan.

Meskipun teori ini memiliki keunggulan dalam mencapai efesiensiorganisasi, sekarang ini tidak banyak berkembang karena sudah tidak sesuai dengan perkembangan jaman yang semakin global. Patokan-patokan pada teori klasikal sudah tidak mencukupi pengaruh globalisasi yang semakin bergolak. Sehingga muncul teori neo klasik.

Contoh dalam teori ini pentingnya manajer mempertahankan wewenang formal, tetapi sekarang karyawan semakin terdidik sehingga mereka kurang dapat menerima wewenang formal.

Kelemahan teori klasik menurut Filley, Keer dan Hous dalam Nanang Fatah adalah: 1) teori klasik adalah teori yang terikat waktu, hanya cocok diterapkan pada permulaan awal abad duapuluh, 2) teori ini mempunyai ciri-ciri deterministik, hanya menekankan pada prinsip-prinsip manajemen tanpa memperhitungkan dimensi dalam manajemen, dan 3) asumsi teori ini dirumuskan secara eksplisit.

2) Teori neo klasik

Teori ini muncul karena pada manajer terdapat kelemahan dengan teori klasik. Teori ini berasumsi bahwa manusia itu makhluk sosial dengan mengaktualisasikan, manajemen dapat bekerja secara efisien dan tetap hidup jika tujuan organisasi dan kebutuhan perorangan yang bekerja dijaga dengan baik.

Dua hal yang paling penting dalam teori Vromm adalah pembedaan antara imbalan instrinsik dan ekstrinsik dan spesifikasi dari suatu keadaan di mana ekspektasi dan nilai mempengaruhi kualitas pekerjaan seseorang. Seorang 
manajer harus menilai dan mempertimbangkan struktur imbalan dengan hati-hati melalui perencanaan yang teliti.

Pemahaman perilaku akan menunjukkan keefektifan tugas yamg harus dilakukan seorang manajer walaupun hal tersebut merupakan bidang yang amat rumit. Perilaku seseorang dipengaruhi tiga variable, yaitu 1) variable individu, mencakup keterampilan mental, fisik, latar belakang keluarga, tingkat sosial, pengalaman, umur dan jenis kelamin, 2) variable organisasi, mencakup sumber daya yang tersedia, gaya kepemimpinan, sistem imbalan, struktur organisasi, dan desain pekerjaan, dan 3) variable psikologi, mencakup persepsi sikap, kepribadian, proses belajar dan motivasi.

\section{3) Teori modern}

Pendekatan ini di dasarkan hal-hal yang bersifat situasional. Asumsi yang dipakai adalah bahwa orang itu berlainan dan berubah, baik kebutuhannya, reaksinya tindakannya sesuai dengan lingkungan. Manajemen dipandang sebagai suatu sistem didasarkan pada asumsi bahwa organisasi merupakan sistem terbuka dan tujuan organisasi mempunyai kebergantungan.

Teori modern mempunyai pandangan bahwa organisasi itu terbuka dan kompleks. Analisis sistem, rancangan sistem, dan manajemen member petunjuk dalam mengoperasionalkan pendekatan sistem merupakan tiga unsur pokok yang berusaha mengenal esensi keterpaduan berbagai unsur dalam memecahkan masalah yang sifatnya kompleks, termasuk pendidikan.

\section{b. Fungsi-fungsi Manajemen}

Menurut Sondang P. Siagian fungsi-fungsi manajemen mencakup:

1. Perencanaan (planning) dapat didefenisikan sebagai keseluruhan proses pemikiran dan penentuan secara matang tentang hal-hal yang akan dikerjakan dimasa yang akan datang dalam rangka mencapai tujuan yang telah ditetapkan.

2. Pengorganisasian (Organizing) adalah keseluruhan proses pengelompokan orang-orang, alat-alat, tugas-tugas, tanggung jawab dan wewenang sedemikian rupa sehingga menciptakan suatu organisasi yang dapat digerakkan sebagai suatu kesatuan dalam rangka pencapaian tujuan yang telah di tentukan.

3. Penggerakan (Motivating) dapat didefenisikan sebagai keseluruhan proses pemberian dorongan bekerja kepada para bawahan sedemikian rupa sehingga mereka mau bekerja dengan ikhlas demi tercapainya tujuan organisasi dengan efesien dan ekonomis.

4. Pengawasan (Controlling) adalah proses pengamatan pelaknsanaan seluruh kegiatan organisasi untuk menjamin agar semua pekerjaan yang sedang dilakukan berjalan sesuai dengan rencana yang telah ditentukan sebelumnya.

5. Penilaiyan (Evaluation) adalah fungsi organik administrasi dan manajemen yang terakhir. Defenisinya ialah proses pengukuran dan perbandingan hasil- 
hasil pekerjaan yang nyatanya dicapai dengan hasil-hasil yang seharusnya dicapai.

Sedangkan menurut George R. Terry dan Liesli W. Rue fungsi-fungsi manajemen yaitu:

1. Planning, menentukan tujuang yang hendak dicapai selama suatu masa yang akan datang dan apa yang harus diperbuat agar dapat mencapai tujuan-tujuan itu.

2. Organizing, mengelompokkan dan menentukan berbagai kegiatan penting dan memberikan kekuasaan untuk melaksanakan kegiatan-kegiatan itu.

3. Staffing, menentukan keperluan-keperluan sumber daya manusia, pengarahan, penyaringan, latihan, dan pengembangan tenaga kerja.

4. Motivating, mengarahkan atau menyalurkan perilaku manusia kearah tujuantujuan.

5. Controlling, mengukur pelaksanaan dengan tujuan-tujuan menentukan sebabsebab penyimpangan dan pengambilan tindakan-tindakan korelatif.

Joseph L. Massie (1985:7) mengemukakan 7 fungsi-fungsi manajemen diantaranya yaitu:

1. Pengambilan keputusan ialah proses pemilihan arah langkah yang harus diambil dan alternatif -alternatif yang ada untuk mencapai hasil yang diinginkan.

2. Pengorganisasian proses penentuan struktur dan alokasi kerja.

3. Pengisian staf proses yang dilakukan para manajer untuk menseleksi, melatih, mempromosikan, dan membebas tugaskan bawahan.

4. Perenacanaan ialah proses seorang manajer akan masa depan dan menemukan alternatif-alternatif arah langka yang terbuka untuknya.

5. Pengawasan proses mengukur pelaksanaan yang berlaku sekarang dan memberpaduan kearah sasaran yang telah ditetapkan sebelumnya.

6. Komunikasi adalah proses pengalihan ide-ide kepada orang lain untuk keperluan mencapai hasil yang diinginkan.

7. Mengarahkan proses bimbingan pelaksanaan para bawahan menuju kesasaran bersama.

c. Pelaksanaan Fungsi-fungsi Manajemen

Menurut Hasibuan mengemukakan pelaksanaan fungsi manajemen adalah sebagai berikut:

1) Perencanaan

Perencanaan adalah proses penentuan tujuan dan pedoman pelaksanaan, dengan memilih yang lebih terbaik dari alternatif-alternatif yang ada. Harold Koontz dan Cyril O'Donnel mengatakan perencanaan adalah fungsi seorang manajer yang berhubungan dengan memilih tujuan-tujuan, kebijaksanaankebijaksanaan, prosedur-prosedur, dan program-program dari alternatif- 
alternatif yang ada. Jadi masalah perencanaan adalah masalah "memilih" yang terbaik dari beberapa alternatif yang ada.

2) Pengorganisasian

Pengorganisasian adalah suatu proses penentuan, pengelompokan, dan pengaturan bermacam-macam aktivitas yang diperlukan untuk mencapai tujuan. Menempatkan orang-orang pada setiap aktivitas ini, menyediakan alatalat yang diperlukan, menetapkan wewenang yang secara relatif didelegasikan kepada setiap individu yang akan melakukan aktifitas-aktifitas tersebut. Pengorganisasian adalah tindakan mengusahakan hubungan-hubungan kelakuan yang efektif antara orang-orang, sehingga mereka dapat bekerja sama secara efesien, dan dengan demikian memperoleh kepuasan pribadi dalam hal melaksanakan tugas-tugas tertentu dalam kondisi lingkungan tertentu guna mencapai tujuan atau sasaran tertentu. Sedangkan penulis mengatakan bahwa pengorganisasian adalah dimana didalam suatu perusahaan atau kelompok yang dapat melaksanakan suatu perencanaan organisasi untuk mencapai tujuan organisasi yang diinginkan oleh manajer.

3) Pengarahan

Pengarahan adalah mengarahkan semua bawahan, agar mau bekerja sama dan bekerja efektif untuk mencapai tujuan. Pengarahan adalah membuat semua anggota kelompok agar mau bekerja sama dan bekerja secara ikhlas serta bergairah untuk mencapai tujuan sesuai dengan perencanaan dan usaha-usaha pengorganisasian. Sedangkan penulis mengatakan bahwa pengarahan adalah dimana seorang pemimpin dapat mengarahkan dan mengatur para bawahannya agar dapat bekerja secara efektif dan efesien guna mendapatkan tujuan yang diinginkan oleh suatu perusahaan.

4) Pengendalian

Pengendalian adalah proses pengaturan berbagai faktor dalam suatu perusahaan agar sesuai dengan ketetapan-ketetapan dalam rencana. Pengendalian adalah mengukuran dan perbaikan terhadap pelaksanaan kerja bawahan, agar rencana-rencana yang telah dibuat untuk mencapai tujuantujuan dapat terlaksanakan.

Dalam prakteknya pembagian fungsi fundamental ini tidak dapat dibedakan secara tajam dan tegas, karena setiap manajer (top manajer, middle manajer dan lower manager), dalam uasah atau aktivitas-aktivitas untuk mencapai tujuan harus melaksanakan semua fungsi tersebut, hanya skop dan penekanannya yang berbeda-beda. Setiap manajer dalam pelaksanaan tugasnya aktivitasnya, dan kepemimpinannya untuk mencapai tujuan harus melakukan "perencanaan, pengorganisasian, pengarahan, dan pengendalian" dengan baik (Hasibun, 2011:40-41). 


\section{Mutu Pendidikan}

a. Pengertian mutu pendidikan

Secara umum, mutu adalah gambaran dan karakteristik menyeluruh dari barang atau jasa yang menunjukkan kemampuannya dalam memuaskan kebutuhan yang diharapkan atau yang tersirat. Dalam konteks pendidikan, pengertian mutu mencakup input, proses, dan output pendidikan (http//www.rokhim.net/2013/04).

Input pendidikan adalah segala sesuatu yang harus tersedia tersedia karena dibutuhkan untuk berlangsungnya proses. Sesuatu yang dimaksud berupa sumber daya dan perangkat lunak serta harpan-harapan sebagai pemandu bagi berlangsungnya proses. Input sumber daya meliputi sumber daya manusia (kepala sekolah, guru termasuk guru BP, staf, siswa) dan sumber daya selebihnya (peralatan, perlengkapan, uang, bahan, dsb). Input perangkat lunak meliputi struktur organisasi sekolah, peraturan perundang-undangan, deskripsi tugas, rencana, program, dsb. Input harapan-harapan berupa visi, misi, tujuan, dan sasaran-sasaran yang ingin dicapai oleh sekolah. Kesiapan input sangat diperlukan agar proses dapat berlangsung dengan baik. Oleh karena itu, tinggi rendahnya mutu input dapat diukur dari tingkat kesiapan input. Makin tinggi tingkat kesiapan input, makin tinggi pula mutu input tersebut.

Proses pendidikan merupakan berubahnya sesuatu menjadi sesuatu yang lain. Sesuatu yang berpengaruh terhadap berlangsungnya proses disebut input, sedangkan sesuatu dari hasil proses disebut output. Dalam pendidkan berskala mikro, proses yang dimaksud adalah proses pengambilan keputusan, proses pengelolaan kelembagaan, proses pengelolaan program, proses belajar mengajar, dan proses monitoring dan evaluasi, denghan catatan bahwa proses belajar mengajar memiliki tinggi kepentingan tertinggi dibandingkan dengan prosesproseslainnya.

Proses dikatakan bermutu tinggi apabila pengorganisasian dan penyerasian serta pemanduan input sekolah (guru, siswa, kurikulum, uang, peralatan, dsb) dilakukan secara harmonis, sehingga mampu menciptakan situasi pembelajaran yang menyenangkan (enjoyable learning), mampu mendorong motivasi dan minat belajar, dan benar-benar mampu memberdayakan peserta didik. Kata memberdayakan mengandungarti bahwa peserta didik tidak sekedar menguasai pengetahuan yang diajarkan oleh gurunya, akan tetapi pengtahuan tersebut juga telah menjadi muatan nurani peserta didik, dihayati, diamalkan dalam kehidupan sehari-hari dan yang lebih penting lagi peserta didik tersebut mampu belajar secara terus menerus (mampu mengembangkan dirinya).

Saleha (http:/003.blogspot.com/2013/10/) mengemukakan Output pendidikan adalah merupakan kinerja sekolah. Kinerja sekolah adalah prestasi sekolah yang dihasilkan dari proses/perilaku sekolah. Kinerja sekolah dapat diukur dari kualitasnya (menunjukkan kepada suatu ukuran penilaian atau penghargaan), 
produktivitasnya (perbandingan terbaik antara hasil yang di peroleh output dengan jumlah sumber yang dipergunakan input), efektivitasnya (ukuran keberhasilan tujuan organisasi), efesiensinya (bagaimana tujuan itu dicapai dengan memiliki tingkat efesiensi waktu, biaya, tenaga dan sarana), inovasinya (suatu ide, barang, metode, yang dirasakan atau diamati sebagai hal yang baru bagi hasil seseorang kelompok orang (masyarakat), baik berupa hasil inverse (penuan baru) atau discovery (baru ditemukan orang), yang digunakan untuk mencapai tujuan pendidikan atau untuk memecahkan masalah pendidikan), kualitas kehidupan kerjanya (teknik manajemen yang mencakup gugus kendali mutu, pengayaan pekerjaan, suatu pendekatan untuk bernegosiasi dengan serikat pekerja), dan moral kerjanya (sikap perorangan dan kelompok terhadap lingkungan kerjanya dan siakp untuk bekerja sebaik-baiknya dengan mengarahkan kemampuan yang dimiliki secara sukarela).

b. Aspek-aspek peningkatan mutu pendidikan

Untuk menguraikan masalah tersebut, penulis membahas tiga komponen yang sangat terkait dan memiliki kedudukan strategis, yaitu:

1. Pendidik/Guru

Dalam Undang-Undang Nomer 20 tahun 2003, dinyatakan bahwa guru adalah "tenaga pendidik yang beriman dan bertakwa terhadap Tuhan yang Maha Esa, berwawasan pancasila, dan Undang-undang Dasar tahun 1945 serta memiliki kualifikasi sebagai tenaga pengajar". Jadi seorang guru adalah memiliki kepribadian sebagai berikut:

Memiliki loyalitas terhadap pemerintah, berdedikasi terhadap tugasnya, iaharus ikhlas dan mencintai tugasnya, peka terhadap tabiat murid, sehingga ia harus memperhatikan tingkat kecerdasan murid-muridnya, bersifat terbuka dan berterus terang.

Dengan demikian seorang guru menjalankan tugas profesinya dituntut suatu ketauladanan yang pantas dan efektif bagi murid, sehingga dengan sendirinya murid dapat meningkatkan prestasi belajarnya.

2. Kurikulum

Dalam undang-undang nomer 20 tahun 2003 tentang Sistem Pendidikan Nasional yang dinyatakan bahwa:

Kurikulum disusun untuk mewujudkan tujuan pendidikan nasional dengan memperhatikan tahap perkembangan peserta didik dan kesesuaiannya dengan lingkungan, kebutuhan pembangunan nasional, perkembangan ilmu pengetahuan dan teknologi serta kesenian sesuai dengan jenis dan jenjang masing-masing satuan pendidikan.

3. Pengajaran

Pengajaran adalah upaya guru dalam mengoperasionalkankurikulum, agar diserap peserta didik untuk peningkatan perilaku kognitif, afektif dan 
psikomotorik. Pengajaran sebagai suatu sistem terdiri atas komponen tujuan, metode dan alat serta penilaian. Dalam hubungan ini, tujuan menempati posisi kunci, bahan adalah isi mengajar yang apabila dipelajari siswa, maka diharapkan tujuan akan tercapai. Metode dan alat berperan sebagai perangkat pembantu untuk memudahkan guru mengajar dan siswa belajar, sedangkan penilaian berkedududkan sebagai alat duga untuk mengukur kualitas dan kuantitas tujuan dan proses pengajaran yang telah tercapai.

Ketiga komponen yang dikemukakan di atas, guru menduduki posisi sentral, sebab peranannya sangat menentukan. Olehnya itu, guru harus mampu menterjemahkan nilai-nilai yang terdapat dalam kurikulum melalui pengajaran untuk siswa secara optimal. Seorang guru dituntut memiliki wawasan profesionalisme, yaitu wawasan yang berhubungan dengan mata pelajaran yang diajarkan dan wawasan yang berhubungan dengan kependidikan untuk menyampaikan isi pengajaran kepada siswa/murid.

c. Faktor-faktor yang mempengaruhi peningkatan mutu pendidikan

Untuk mencapai kualitas pembelajaran dapat dikembangan aspek-aspek yang mempengaruhi peningkatan mutu pendidikan, seperti aspek tingkat kelembagaan dan aspek individu guru.

1. Tingkat kelembagaan

a) Perlu dikembangkan berbagai fasilitas kelembagaan dalam membangun sikap, semangat, dan budaya perubahan.

b) Peningkatan kemampuan pembelajaran para guru dilakukan melalui berbagai kegiatan profesional secara periodic dan berkelanjutan, misalnya sekali dalam setiap semester yang dilakukan oleh masing-masing lembaga pendidikan sebelum awal setiap semester dimulai.

c) Peningkatan kemampuan pembimbingan profesional siswa melalui berbagai kegiatan profesional di sekolah secara priodik, misalnya sekali setiap tahun yang dilaksanakan oleh lembaga pendidikan bekerja sama dengan dinas pendidikan setempat.

d) Peningkatan kualitras pelaksanaan praktek pengalaman lapangan ( $P P L$ ) ditempat praktek, dengan menggiatkan kegiatan kolaborasi lembaga pendidikan dengan tempat praktek serta penyelenggaraan uji kompetensi profesional siswa pada akhir program pendidikan sebelum mereka dinyatakan lulus. Kolaborasi ini berlaku pula dengan asosiasi profesi yang relevan (Mulyani, 2003:73).

2. Individu guru

Secara operasional hal yang terkait pada kinerja profesional guru adalah:

a) Melakukan perbaikan pembelajaran secara terus menerus berdasarkan hasil penelitian tindakan kelas atau catatan pengalaman kelas dan/atau catatab perbaikan. 
b) Mencoba menerapkan berbagai model pembelajaran yang relevan untuk pembelajaran di kelas maupun kegiatan praktikum.

c) Guru perlu dirangsang untuk membangun sikap positif terhadap belajar, yang bermula pada peningkatan kualitas proses dan hasil belajar siswa. Untuk itu perlu diterapkan berbagai diskursus akademis antar guru dalam menggali, mengkaji dan memanfaatkan berbagai temuan penelitian dan hasil kajian konseptual untuk meningkatkan kualitas pembalajaran. Dengan cara itu guru secara perseorangan dan kelompok akan selalu didorong dan ditantang untuk selalu berusaha tampil beda dan unggul.

d) Komunitas guru yang penuh dengan diskursus akademis dan profesional dengan nuansa kesejawatan yang berorieantasi pada peningkatan kinerja yang unggul tersebut akan memiliki dampak ganda. Di satu sisi komitmen dan kompetensi guru akan selalu terjaga dan terpelihara.

Dengan demikian dapat dipahami bahwa peningkatan mutu pendidikan tidak terlepas dari kualitas sumber daya manusia yang dimiliki. Oleh sebab itu Lembaga Pendidikan juga harus mampu memenuhi kebutuhan sumber daya manusia baik jumlah maupun kualitas dengan meningkatkan sumber daya pendidikan untuk memasok kebutuhan sumber daya manusia sesuai dengan permintaan dan meningkatkan proses pendidikan setempat dengan mengembangkan unsur-unsur pokok dan penunjang yang diperlukan. Peningkatan kualitas pembelajaran perlu menggunakan strategi-strategi yang dapat diterapkan pada masing-masing lembaga dengan memperhatikan karakteristik lembaga. Dengan sumber daya manusia yang berkualitas, diharapkan lembaga pendidikan akan menjadi lembaga yang mampu mengahadapi tantangan masa depan dengan efektif.

\section{DAFTAR PUSTAKA}

Departemen RI, Pedoman Pelaksanaan Pendidikan SD, Jakarta: Proyek Pembinaan Pendidikan pada Sekolah Umum, 1985/1986.

Dikmenum, Pengembangan Kecakapan Hidup (http://cleringhouse.dikmenum. co.id), diakses tanggal 26 Mei 2016.

Getteng, Abd. Rahman. Menuju Guru Profesional dan Beretika, Yogyakarta: Grha Guru,2009.

Hasibun, Malayu S.P, Manajemen Dasar, Pengertian dan Masalah. Cet VI, Jakarta: PT Bumi Aksara,2011.

Hasibun, Malayu S.P, Manajemen. Cet III, Jakarta: Bumi Aksara, 2009.

Hasibun, Melayu S.P, Manajemen Sumber Daya Manusia. Cet IX, Jakarta: Bumi Aksara, 2007. 
Kalla Group, Al-Qur'an dan Terjemahan, Semarang: PT. Karya Toha Putra, 2013

Manullang, M., Dasar-Dasar Manajemen, Jakarta: Erlangga, 1985.

Moleng. Lexy J, Metode Penelitian Kualitatif, Bandung: Remadja Rosdakarya. 1999.

Mulyani, Kurikulum Berbasis Kompetensi, Jakarta: Remaja Rosda Karya, 2003.

Mulyasa, Manajemen Berbasis Sekolah, Bandung: PT Remaja Rosda Karya, 2002.

Nana, Sudjana, CBSA dalam Proses Belajar Mengajar, Bandung: Sinar Baru Algensido, 1996.

Pujayanti. Nining, Tesis Peranan Kepala Sekolah Sebagai Supervisor Dalam Meningkatkan Dalam Pengembangan Staf dan Kurikulum. Semarang: Universitas Negeri Semarang. 2006

Republik Indonesia, Pasal 3 UU No. 20 Tahun 2003, Bandung: Citra Umbara, 2003.

Rokhim, Pengertian Mutu Pendidikan, (http://www.rokhim.net/2013/04) Diakses pada Tanggal 26 Mei 2016.

Sagala, Syaiful, Manajemen Strategi dalam Peningkatan Mutu Pendidikan, Cet V, Bandung: CV. Alfabeta, 2001.

Saleha, Manajemen Berbasis Sekolah, (http:/003.blogspot.com/2013/10/ diakses pada tanggal 09 juni 2016).

Terry, Georger R dan Rue, Laslie W, Dasar-Dasar Manajemen, Jakarta: Bumi Aksara, 2005.

Tilar, H.A.R, Manajemen Pendidikan Nasional, Bandung: PT Remaja Rosda Karya,1992.

Tim Dosen Administrasi Pendidikan Universitas Pendidikan Indonesia, Manajemen Pendidikan. Bandung: Alfabera. 2011

Undang-Undang Nomer 20 Tahun 2003, Tentang Sistem Pendidikan Nasional, t.t.: t.p., t.th

Yuku, Kamus Besar Bahasa Indonesia Mobile (Ver.1.1.3; Jakarta: Yuku Mobile, 2013) 